\title{
Pengaruh Gaya Kepemimpinan Situasional, Budaya Organisasi Dan Kompensasi Terhadap Kinerja
}

\author{
P. Hellen Wijaya, Christina Catur Widayati, dan Chichi Rahmayanti \\ Fakultas Ekonomi Universitas Tarumanagara, Universitas Mercu Buana, \\ christinewijaya73@yahoo.co.id, / catur.widayati@mercubuana.ac.id
}

\begin{abstract}
This research aims to examine and analyze the influence of situational leadership style, organizational culture and compensation on performance of employees. The methods used in this research is descriptive method. The object of this research is all staff office division who worked in PT. CIMB NIAGA Kuningan Plaza Branch Office with a population 75 people. The sampling using the method of population (census) is to examine the entire population. The approach used in this research is a Structural Equation Models (SEM) with Smart analysis tools-PLS.The results showed situational leadership style gives a positive and significant influence on employee performance.organizational culture gives a positive and significant influence on employee performance. Compensation provides a positive and significant effect on performance employees. This is evidenced from the results of hypothesis testing (t-test) which shows the significance value of the independent variables.
\end{abstract}

Keywords: Situational Leadership Style, Organizational Culture, Compensation and Performance Of Employees.

\begin{abstract}
Abstrak: Penelitian ini bertujuan untuk menguji dan menganalisis pengaruh gaya kepemimpinan situasional, budaya organisasi dan kompensasi terhadapkinerja karyawan. Metode penelitian yang digunakan dalam penelitian ini adalah metode deskriptif. Objek penelitian ini adalah seluruh karyawan yang bekerja di PT.CIMB NIAGA Cabang Kuningan Plaza dengan populasi 75 orang. Pengambilan sampel menggunakan metode populasi (sensus) yaitu dengan meneliti seluruh populasi. Pendekatan yang digunakan dalam penelitian ini adalah Structural Equation Model (SEM) dengan alat analisis SmartPLS. Hasil penelitian menunjukan gaya kepemimpinan situasional memberikan pengaruh positif dan signifikan terhadap kinerja karyawan. Budaya organisasimemberikan pengaruh positif dan signifikan terhadap kinerja karyawan. Kompensasi memberikan pengaruh positif dan signifikan terhadap kinerja karyawan. Hal ini dibuktikan dari hasil pengujian hipotesis (uji t) yang menunjukan nilai signifikasi dari variabel bebas.
\end{abstract}

Kata kunci: Gaya Kepemimpinan Situasional, Budaya Organisasi, Kompensasi,Kinerja Karyawan.

\section{PENDAHULUAN}

Setiap perusahaan melakukan berbagai aktivitas untuk mencapai tujuan yang telah ditetapkan sebelumnya. Perusahaan membutuhkan adanya faktor sumber daya manusia yang potensial dalam penentu tercapainya tujuan perusahaan.Pengelolaan sumber daya manusia yang efektif dapat dilihat dari kondisi sumber daya manusianya, seperti dari tingkat kinerja karyawan. Faktor-faktor yang dapat mempengaruhi kinerja karyawan yaitu 
kualitas gaya kepemimpinan dan budaya organisasi yang diterapkan dalam perusahaan serta kompensasi yang diberikan perusahaan kepada para karyawannya. Dalam melaksanakan pekerjaan, peran kepemimpinan dirasa sangat penting, kepemimpinan merupakan kemampuan untuk mempengaruhi suatu kelompok guna mencapai sebuah visi atau serangkaian tujuan yang telah ditetapkan (Robins dan Judge, 2011).

Menurut Rahmad dan Widayati, (2016) Peran para pemimpin dalam menyatukan orang-orang etnis beraneka warna dan integrasi organisasi untuk mencapai tujuan yang sama jelas penting dalam keberhasilan organisasi atau perusahaan. Kepemimpinan transaksional dan transformasional adalah dua model kepemimpinan yang sering ditemukan dalam banyak aspek organisasi. Masalahnya adalah dalam perspektif budaya tentang seberapa jauh budaya dasar seorang individu mempengaruhi model kepemimpinan individu sehingga ia memiliki kecenderungan baik kepemimpinan transaksional atau transformasional, sementara Naor et al., (2008) mengungkapkan bahwa budaya memiliki peran sebagai motivasi untuk mempengaruhi kualitas pekerjaan seseorang dan metode mereka dalam melakukan pekerjaan mereka meskipun penelitian tidak menunjukkan secara eksplisit pengaruh antara budaya dan kepemimpinan, tetapi ada hubungan erat antara pengaruh budaya dan prestasi kerja.

Pemimpin yang efektif sanggup mempengaruhi para pengikutnya untuk mempunyai optimisme yang lebih besar, rasa percaya diri, serta komitmen kepada tujuan dan misi organisasi, sementara Djakasaputra, Widayati dan Septy (2017) mengatakan bahwa seorang pemimpin harus mampu mempengaruhi para bawahannya untuk bertindak sesuai dengan visi, misi dan tujuan perusahaan. Pemimpin harus mampu memberikan wawasan, membangkitkan kebanggaan, serta menumbuhkan sikap hormat dan kepercayaan dari bawahannya. Hal ini sejalan dengan usaha untuk menumbuhkan komitmen organisasi dari diri karyawan. Sehingga pemimpin nantinya dapat meningkatkan kepuasan karyawan terhadap pekerjaannya serta dapat meningkatkan kinerja karyawan dengan lebih efektif.

Salah satu teori kepemimpinan yang terkenal ialah teori kepemimpinan situasional, yang diciptakan oleh Hersey dan Blanchard. Menurut Daft (2012) bahwa model kepemimpinan situasional yang diciptakan oleh Hersey dan Blanchard ini memfokuskan pendekatan yang berfokus pada perhatian yang besar pada karakterisik karyawan dalam menentukan perilaku kepemimpinan yang tepat. Setiap organisasi memiliki budaya organisasi yang berfungsi untuk membentuk aturan dan pedoman dalam berfikir dan bertindak dalam pencapaian tujuan yang ditetapkan. Budaya organisasi menurut Wibowo (2010), adalah filosofi dasar organisasi yang memuat keyakinan, norma-norma, dan nilainilai tersebut menjadi pegangan semua sumber daya manusia adalam organisasi dalam melaksanakannya.Faktor penting lain yang mempengaruhi kinerja karyawan adalah kompensasi. Kompensasi yang tepat baik bagi keinginan karyawan maupun kemampuan perusahaan mampu menciptakan hubungan kerjasama yang sehat untuk kemajuan kinerja perusahaan. Menurut Hasibuan (2012) Kompensasi adalah semua pendapatan yang berbentuk uang, barang langsung atau tidak langsung yang diterima karyawan sebagai imbalan atas jasa yang diberikan kepada perusahaan. Penelitianinidilakukan di PT Bank CIMB Niaga Cabang Kuningan Plaza. Sebuah perusahaan yang bergerak di bidangPerbankan.

Gaya kepemimpinan situasional merupakan gaya kepemimpinan yang efektif dibutuhkan dalam perusahaan ini untuk dapat meningkatkan kinerja semua karyawan dalam mencapai tujuan yang telah ditetapkan perusahaan. Selain gaya kepemimpinan situasional, faktor yang mempengaruhi kinerja karyawan adalah budaya organisasi. 
Budaya organisasi yang diterapkan tidak sama antara kantor cabang dengan cabang kios, seharusnya setiap hari 15 menit sebelum jam kerja dilakukannya morning briefing kemudian dilanjutkan dengan kegiatan morning line up yaitu dengan cara semua karyawan berdiri di depan pintu masuk kemudian memberikan salam kepada nasabah yang datang pertama kali. Namun hal tersebut biasanya hanya dilakukan di kantor cabang saja, untuk cabang kios tidak selalu menerapkan hal tersebut. Seharusnya budaya tersebut dilakukan merata disemua cabang termasuk cabang kios untuk mengurangi keterlambatan karyawan, karena dengan adanya kegiatan tersebut karyawan diharuskan datang satu jam sebelum jam masuk kerja. Agar pada saat jam buka counter tepat jam delapan pagi, semua karyawan siap untuk bekerja dan melayani nasabah. Pemberian kompensasi berupa bonus kepada karyawan berdasarkan hasil laporan penilaian setiap tahun yang diperoleh karyawan. Akan tetapi hal tersebut masih dirasakan kurang memuaskan para karyawan, karena untuk pemberian uang makan dan uang parkir karyawan setiap bulannya tidak dibayarkan tepat waktu oleh perusahaan. Kemudian besarnya jumlah tunjangan insentif ATM disemua cabang besarnya sama, padahal setiap cabang memiliki jumlah mesin ATM yang berbeda-beda. Sehingga beban kerjanya pun berbeda disetiap cabang.

\section{KAJIAN TEORI}

Gaya KepemimpinanSituasional. Menurut (Robbin, 2005) kepemimpinan situasional adalah teori yang memfokuskan pada pengikut. Pendekatan ini memfokuskan banyak perhatian pada karakteristik karyawan, maksudnya para karyawan memiliki tingkat kesiapan yang berbeda-beda. Orang yang memiliki tingkat kesiapan rendah karena sedikitnya kemampuan atau pelatihan, membutuhkan gaya kepemimpinan yang berbeda dengan orang-orang yang memiliki tingkat kesiapan yang tinggi.

Indikator Gaya Kepemimpinan Situasional. Menurut Sedarmayanti (2011) ada empat dimensi teori gaya kepemimpinan situasional Hersey dan Blanchard yaitu:

a) Telling / memberitahukan. Dengan indikator: (i) Pimpinan mampu memberi perintah kerja dengan jelas; (ii) Pimpinan selalu memberi pengarahan dalam menyelesaikan masalah pekerjaan.

b) Selling / menjajakan. Dengan indikator: (i) Pimpinan memberikan kesempatan kepada bawahan untuk berpendapat; (ii) Pimpinan selalu memberikan dorongan motivasi kepada bawahan dalam menyelesaikan pekerjaan.

c) Participating / mengikutsertakan. Dengan indikator: (i) Pimpinan meminta masukan dari bawahan dalam pengambilan keputusan; (ii) Pimpinan ikut serta dalam menyelesaikan masalah pekerjaan.

d) Delegating / wewenang. Dengan indikator: (i) Pimpinan memberikan tanggung jawab penuh kepada bawahan dalam menyelesaikan pekerjaan.

Budaya Organisasi. Menurut Rivai dan Mulyadi (2012) mendefinisikan bahwa "Budaya organisasi adalah suatu kerangka kerja yang menjadi pedoman tingkah laku sehari-hari dan membuat keputusan untuk karyawan dan mengarahkan tindakan mereka untuk mencapai tujuan organisasi”.

Indikator Budaya Organisasi. Menurut Robbins dan Judge (2007) yaitu:

1) Inovasi: (i) Sejauh mana pegawai didorong untuk menjadi inovatif; (ii) Sejauh mana pegawai didorong untuk berani mengambil resiko. 
2) Perhatian terhadap detail: (i) Sejauh mana karyawan dihadapkan menunjukkan kecermatan.

3) Berorientasi kepada hasil: (i) Sejauh mana manajemen yang berfokus pada hasil bukan pada teknik yang digunakan untuk mencapai hasil tersebut

4) Berorientasi kepada manusia: (i) Sejauh mana keputusan manajemen mempertimbangkan efek dari hasil kerja pegawai dalam organisasi.

5) Berorientasi tim: (i) Sejauh mana kegiatan-kegiatan kerja di organisasi pada tim ketimbang pada individu-individu

6) Agresivitas: (i) Sejauh mana pegawai yang agresif dan kompetitif

7) Stabilitas: (i) Sejauh mana kegiatan organisasi menekankan mempertahankan status quo berbeda dengan pertumbuhan.

Kompensasi. Menurut Veithzal Rivai (2010)Kompensasi merupakan sesuatu yang diterima karyawan sebagai pengganti kontribusi mereka pada perusahaan. Indikator Kompensasi. Menurut Hasibuan (2012) kompensasi dibedakan menjadi dua yaitu kompensasi langsung (Direct Compensation) dan kompensasi tidak langsung (Indrirect Compensation).

a) Kompensasi langsung (Direct Compensation) adalah berupa gaji, upah, dan upah insentif. Gajiadalah balas jasa yang dibayar secara periodik kepada karyawan tetap serta mempunyai jaminan yang pasti. Maksudnya, gaji akan tetap dibayarkan walaupun pekerja tersebut tidak masuk kerja.

Upah adalah balas jasa yang dibayarkan kepada pekerja harian dengan berpedoman atas perjanjian yang disepakati membayarnya.

Upah Insentif,adalah tambahan balas jasa yang diberikan kepada karyawan tertentu yang prestasinya diatas prestasi standar. Upah insentif ini merupakan alat yang dipergunakan pendukung prinsip adil dalam pemberian kompensasi.

b) Kompensasi tidak langsung (Indirect Compensation) adalah kompensasi (balas jasa) langsung merupakan hak bagi karyawan dan menjadi kewajiban perusahaan untuk membayarnya.

Benefit dan Service adalah kompensasi tambahan yang diberikan berdasarkan kebijaksanaan perusahaan terhadap semua karyawan dalam usaha untuk meningkatkan kesejahteraan mereka. Seperti tunjangan hari raya, fasilitas kantor, pakaian dinas, mushala, olahraga, dan darmawisata.

Kinerja. Menurut Mangkunegara (2013) bahwa kinerja karyawan adalah hasil kerja secara kualitas dan kuantitas yang dicapai oleh seorang karyawan dalam melaksanakan tugasnya sesuai dengan tanggung jawab yang diberikan kepadanya. IndikatorKinerja. Menurut Wirawan (2009) secara umum dimensi kinerja dapat dikelompokkan menjadi tiga jenis, yaitu:

a. Hasil kerja. Adalah keluaran kerja dalam bentuk barang dan jasa yang dapat dihitung dan diukur. Indikator hasil kerja adalah ketepatan dalam melaksanakan pekerjaan, kepuasan pelanggan, efektifitas melakukan tugas.

b. Perilaku kerja. Adalah ketika berada di tempat kerja karyawan harus memiliki perilaku kerja yang baik. Indikator perilaku kerja meliputi ramah kepada pelanggan, ketelitian dalam bekerja, kerjasama tim.

c. Sifat pribadi yang ada hubungannya dengan pekerjaanadalah sifat pribadi karyawan yang diperlukan dalam melaksanakan pekerjaannya seperti pengetahuan, keterampilan, kemampuan beradaptasi, semangat kerja. 


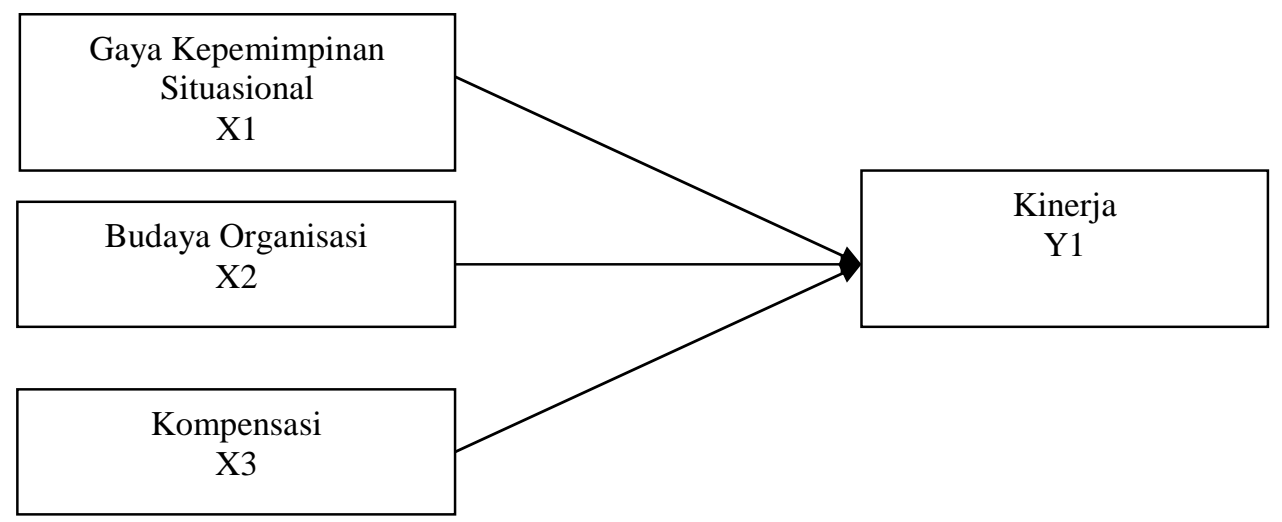

Gambar 1. Rerangka Pemikiran

\section{Hipotesis}

1) Pengaruh Gaya Kepemimpinan Situasional Terhadap Kinerja Karyawan. Penelitian yang dilakukanoleh Kadek Fajar Andika Karma, et al (2016) Hasil penelitian ini menunjukan bahwa variabel gaya kepemimpinan situasional, budaya organisasi dan motivasi berpengaruh positif signifikan terhadap kinerja karyawan. Dengan demikian, hipotesis pertama yang diajukan dalam penelitian ini adalah sebagai berikut:

H1: Gaya kepemimpinan situasional berpengaruh signifikan terhadap kinerja karyawan.

2) Pengaruh Budaya Organisasi Terhadap Kinerja Karyawan. Penelitian yang dilakukan oleh Evi Wahyuni (2015) menunjukan bahwa budaya organisasi dan gaya kepemimpinan berpengaruh positif signifikan terhadap kinerja pegawai. Dengan demikian, hipotesis kedua yang diajukan dalam penelitian ini adalah sebagai berikut:

H2: Budaya organisasi berpengaruh signifikan terhadap kinerja karyawan.

3) Pengaruh Kompensasi Terhadap Kinerja Karyawan. Hasil penelitian yang dilakukanolehSheila Wambui Njoroge, et al., (2015) bahwa variabel kompensasi juga berpengaruh signifikan terhadap kinerja karyawan.Dengan demikian, hipotesis ketiga yang diajukan dalam penelitian ini adalah sebagai berikut:

H3 : Kompensasi berpengaruh signifikan terhadap kinerja karyawan.

\section{METODE}

Waktu \& Tempat Penelitian. Penelitian ini di lakukan mulai dari Oktober 2017 hingga Desember 2017. Pelaksanaan penelitian ini penulis mengambil tempat penelitian pada PT Bank CIMB Niaga yang beralamat di Jalan HR Rasuna Said Kav C11-14 Setiabudi Jakarta Selatan.Untuk memperoleh data guna penyusunan skripsi.

Desain Penelitian. Desain penelitian ini adalah penelitian kausal. Penelitian kausal adalah penelitian yang bertujuan untuk mengetahui tentang hubungan yang bersifat sebab akibat dengan adanya variabel bebas (variable independen) dan variabel terikat (variabel dependen). Penelitian ini dimaksudkan untuk menguji hipotesis adanya pengaruh gaya kepemimpinan situasional, budaya organisasi dan kompensasi terhadap kinerja karyawan PT Bank CIMB Niaga Cabang Kuningan Plaza. 
Skala Pengukuran Variabel. Pengukuran variabel dalam penelitian ini menggunakan skala likert yang digunakan untuk mengukur sikap, pendapat dan persepsi seseorang atau sekelompok orang tentang fenomena sosial (Sugiyono, 2013). Dengan tingkatan skala yang digunakan adalah dari nilai 1 sampai dengan 5 dari sangat tidak setuju, tidak setuju, cukup setuju, setuju, dan sangat setuju (Sugiyono, 2013).

Populasi dan Sampel Penelitian. Sugiyono (2013) menyatakan bahwa, populasi adalah wilayah generalisasi yang terdiri atas obyek atau subyek yang mempunyai kualitas dan karakteristik tertentu yang ditetapkan oleh peneliti untuk dipelajari dan kemudian ditarik kesimpulannya. Populasi dalam penelitian iniberjumlah 75 karyawanpada PT Bank CIMB NiagaCabangKuningan Plaza. Teknik pengambilan sampel menggunakan menggunakan sampling jenuh (sensus), karena jumlah populasi relatif kecil sehingga semua anggota populasi digunakan sebagai sampel.

Metode Analisis Data. Metode analisis data yang digunakan dalam penelitian ini adalah Component atau Variance Based Structural EquationModel dimana dalam pengolahan datanya menggunakan program Partial Least Square (Smart-PLS) versi 3.0 PLS. Langkah-langkah pengujian yang akan dilakukan sebagai berikut:

1. Evaluasi Measurement (outer) Model

a. Converegent Validity. Suatu indikator dikatakan mempunyai valid yang baik jika nilainya lebih besar dari 0,70 sedangkan loading factornya 0,50 sampai dengan 0,60 dapat dianggap cukup (Chin dalam Ghozali, 2014).

b. Discriminant Validity. Model pengukuran dengan refleksi indikator di nilai berdasarkan crossloading pengukuran dengan konstruk. Jika korelasi konstruk dengan item pengukuran lebih besar daripada ukuran konstruk lainnya maka hal tersebut menunjukkan bahwa konstruk laten memprediksi ukuran pada blok mereka lebih baik daripada ukuran pada blok lainnya.

c. Composite Reliability. Pengujian composite reliability bertujuan untuk menguji validitas instrumen dalam suatu model penelitian. Apabila seluruh nilai variabel laten memiliki nilai composite reliability maupun cronbach alpha $\geq 0,7$ hal itu berarti bahwa konstruk memiliki reabilitas yang baik atau kuesioner yang digunakan sebagai alat dalam penelitian ini telah handal atau konsisten.

2. Pengujian Model Struktural atau Uji Hipotesis (Inner Model)

a. Nilai R-square. Melihat nilai R-square yang merupakan uji goodness fit model. Menurut Chin (Ghozali, 2014) nilai R-square untuk variabel laten endogen sebesar 0,67, 0,33 dan 0,19 dalam model struktural mengindikasikan bahwa model tersebut kuat, moderat, dan lemah.

b. Goodness of Fit Model. Pengujian Goodness of Fit model structural pada inner model menggunakan nilai predictive-relevance $\left(\mathrm{Q}^{2}\right)$. Nilai $Q$-square lebih besar 0 (nol) menunjukan bahwa model mempunyai nilai predictive relevance.

c. Hasil Pengujian Hipotesis (Estimasi Koefisien Jalur). Nilai estimasi untuk hubungan jalur dalam model struktural harus signifikan. Nilai signifikan ini dapat diperoleh dengan prosedur boostrapping. Melihat signifikan pada hipotesis dengan melihat nilai koefisien parameter dan nilai signifikasi t-statistic pada algortihm boostrapping report nilai signifikansi t statistik harus lebih besar dari 1,96 .

\section{HASIL DAN PEMBAHASAN}




\section{Hasil Uji Kualitas Data. Evaluasi Measurement (outer) Model}

a. Hasil Pengujian Convergent Validity. Pengujian Convergent Validity dari model pengukuran dengan refleksif indikator dinilai berdasarkan korelasi antara item score atau component score dengan construct score yang dihitung dengan PLS. Indikator individu dianggap valid jika memiliki nilai korelasi di atas 0,70. Namun pada riset pengembangan skala, loading factor 0,50 sampai 0,60 masih dapat diterima.

Berikut hasil output dari penghilangan indikator dan perhitungan kembali:

Tabel 1. Hasil pengujian Convergent Validity(modifikasi)

\begin{tabular}{cccc}
\hline Variabel & Indikator & Outer Loading & Keterangan \\
\hline Gaya & GK2 & 0.778 & Valid \\
Kepemimpinan & GK3 & 0.884 & Valid \\
Situasional & GK4 & 0.722 & Valid \\
(X1) & GK6 & 0.895 & Valid \\
& GK7 & 0.753 & Valid \\
Budaya Organisasi & BO1 & 0.874 & Valid \\
(X2) & BO5 & 0.883 & Valid \\
& BO6 & 0.943 & Valid \\
& BO7 & 0.813 & Valid \\
& BO8 & 0.941 & Valid \\
Kompensasi & K2 & 0.686 & Valid \\
(X3) & K4 & 0.775 & Valid \\
& K5 & 0.810 & Valid \\
& K7 & 0.762 & Valid \\
& K8 & 0.618 & Valid \\
& K9 & 0.579 & Valid \\
& KK2 & 0.834 & Valid \\
KK3 & 0.613 & Valid \\
Kinerja Karyawan & KK5 & 0.532 & Valid \\
(Y) & KK6 & 0.885 & Valid \\
& KK7 & 0.906 & Valid \\
& KK8 & 0.7784 & Valid \\
& KK9 & 0.905 & Valid \\
& & 0.808 & Valid \\
\hline
\end{tabular}

Sumber: Output PLS 


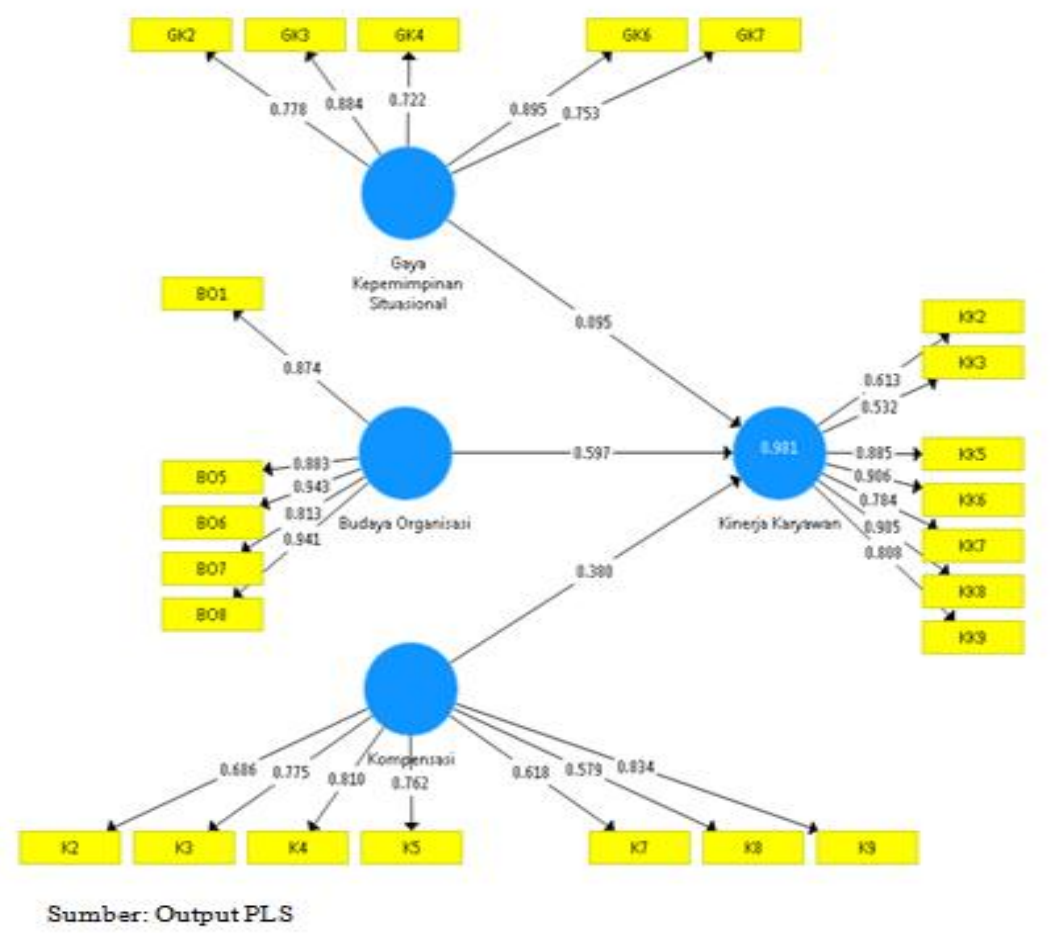

Gambar 2. Hasil Algoritma PLS (modifikasi)

Hasil dari modifikasi pengujian convergent validity pada Gambar 2 dan Tabel 1, dapat dilihat bahwa semua indikator telah memenuhi convergent validity karena memiliki nilai loading factor diatas 0.50 .

b. Hasil Pengujian Discriminant Validity(Cross loadings). Pengujian discriminant validity yaitu indikator reflektif dapat dilihat pada cross loading antara indikator dengan konstruknya. Suatu indikator dapat dinyatakan valid apabila mempunyai loading factor tertinggi kepada konstruk yang dituju dibandingkan denganloading factor kepada konstruk lain. Dengan demikian, konstruk laten memprediksi indikator pada blok mereka lebih baik dibandingkan dengan indikator di blok lain.

Tabel 2. Hasil Pengujian Discriminant Validity (Cross loadings)

\begin{tabular}{ccccc}
\hline & $\begin{array}{c}\text { Gaya } \\
\text { Kepemimpinan } \\
\text { Situasional }\end{array}$ & $\begin{array}{c}\text { Budaya } \\
\text { Organisasi }\end{array}$ & Kompensasi & $\begin{array}{c}\text { Kinerja } \\
\text { Karyawan }\end{array}$ \\
\hline GK2 & 0.778 & 0.213 & 0.356 & 0.306 \\
GK3 & 0.884 & 0.389 & 0.480 & 0.532 \\
GK4 & 0.722 & 0.122 & 0.255 & 0.197 \\
GK6 & 0.895 & 0.395 & 0.482 & 0.524 \\
GK7 & 0.753 & 0.166 & 0.300 & 0.238 \\
BO1 & 0.355 & 0.874 & 0.700 & 0.801 \\
BO5 & 0.344 & 0.883 & 0.806 & 0.880 \\
BO6 & 0.363 & 0.943 & 0.801 & 0.906 \\
BO7 & 0.194 & 0.813 & 0.767 & 0.784 \\
BO8 & 0.348 & 0.941 & 0.810 & 0.905 \\
\hline
\end{tabular}




\begin{tabular}{ccccc}
\hline K2 & 0.426 & 0.462 & 0.686 & 0.613 \\
K3 & 0.206 & 0.722 & 0.775 & 0.792 \\
K4 & 0.348 & 0.641 & 0.810 & 0.805 \\
K5 & 0.518 & 0.543 & 0.762 & 0.643 \\
K7 & 0.325 & 0.374 & 0.618 & 0.463 \\
K8 & 0.292 & 0.352 & 0.579 & 0.414 \\
K9 & 0.446 & 0.694 & 0.834 & 0.808 \\
KK2 & 0.426 & 0.462 & 0.606 & 0.613 \\
KK3 & 0.484 & 0.389 & 0.480 & 0.532 \\
KK5 & 0.344 & 0.883 & 0.806 & 0.885 \\
KK6 & 0.363 & 0.903 & 0.801 & 0.906 \\
KK7 & 0.194 & 0.713 & 0.767 & 0.784 \\
KK8 & 0.348 & 0.841 & 0.810 & 0.905 \\
KK9 & 0.446 & 0.694 & 0.834 & 0.808 \\
\hline
\end{tabular}

Sumber: Output PLS

Dari Tabel di atas terlihat bahwa korelasi konstruk gaya kepemimpinan situasional dengan indikatornya (GK2 sebesar 0.778 , GK3 sebesar 0.884 , GK4 sebesar 0.722 , GK6 sebesar 0.895, dan GK7 sebesar 0.753) lebih tinggi dibanding korelasi indikator gaya kepemimpinan situasional dengan konstruk lainnya, selanjutnya korelasi konstruk budaya organisasi dengan indikatornya (BO1 sebesar 0.874, BO5 sebesar 0.883, BO6 sebesar 0.943, BO7 sebesar 0.813, dan BO8 sebesar 0.941) hal ini membuktikan bahwa indikatornya lebih tinggi dibanding korelasi indikator budaya organisasi dengan konstruk lainnya, kemudian korelasi konstruk kompensasi dengan indikatornya (K2 sebesar 0.686, K3 sebesar 0.775, K4 sebesar 0.810, K5 sebesar 0.762, K7 sebesar 0.618, K8 sebesar 0.579 , dan K9 sebesar 0.834) hal ini berarti indikatornya lebih tinggi dibanding korelasi indikator kompensasi dengan konstruk lainnya, begitupula dengan korelasi konstruk kinerja karyawan dengan indikatornya (KK2 sebesar 0.613, KK3 sebesar 0.532, KK5 sebesar 0.885, KK6 sebesar 0.906, KK7 sebesar 0.784, KK8 sebesar 0.905, dan KK9 sebesar 0.808 ) lebih tinggi daripada korelasi indikator kinerja karyawan dengan konstruk lainnya.

Metode lain untuk melihat discriminant validity adalah dengan melihat nilai square root of average variance extracted (AVE) setiap konstruk dengan korelasi antara konstruk dengan konstruk lainnya dalam model, maka dapat dikatakan memiliki nilai discriminant validity yang baik.

Metode lain untuk melihat discriminant validity adalah dengan melihat nilai average variance extracted (AVE), apabila nilai average variance extracted (AVE) lebih dari 0.50 maka dapat dikatakan memiliki kriteria discriminant yang baik. Selain itu, dapat dilihat pada nilai square root of average variance extracted (AVE) pada Fornell Lacker Criterium, apabila setiap konstruk dengan korelasi antara konstruk dengan konstruk lainnya dalam model lebih besar, maka dapat dikatakan memiliki nilai discriminant validity yang baik.

Tabel 3. HasilPengujian AVE

\begin{tabular}{ll}
\hline \multicolumn{1}{c}{ Variabel } & AVE \\
\hline Gaya Kepemimpinan Situasional & 0.656 \\
Budaya Organisasi & 0.796 \\
Kompensasi & 0.532 \\
Kinerja Karyawan & 0.621 \\
\hline
\end{tabular}


Tabel 4. Hasil Pengujian Discriminant Validity (Fornell Lacker Criterium)

\begin{tabular}{lcccc}
\hline & $\begin{array}{c}\text { Budaya } \\
\text { Organisasi }\end{array}$ & $\begin{array}{c}\text { Gaya } \\
\text { Kepemimpinan } \\
\text { Situasional }\end{array}$ & $\begin{array}{c}\text { Kinerja } \\
\text { Karyawan }\end{array}$ & Kompensasi \\
\hline $\begin{array}{l}\text { Budaya } \\
\text { Organisasi }\end{array}$ & $\mathbf{0 . 8 9 2}$ & & & \\
$\begin{array}{l}\text { Gaya } \\
\begin{array}{l}\text { Kepemimpinan } \\
\text { Situasional }\end{array}\end{array}$ & 0.362 & $\mathbf{0 . 8 1 0}$ & & \\
$\begin{array}{l}\text { Kinerja } \\
\text { Karyawan }\end{array}$ & 0.762 & 0.498 & $\mathbf{0 . 7 8 8}$ & \\
Kompensasi & 0.712 & 0.493 & 0.708 & $\mathbf{0 . 7 2 9}$ \\
\hline Sumber: Output PLS & & & &
\end{tabular}

Dari Tabel 3 dan 4 dapat disimpulkan bahwa akar kuadrat dari average variance extracted $(\sqrt{ }(A V E))$ untuk setiap konstruk lebih besar daripada korelasi antara konstruk yang satu dengan konstruk lainnya dalam model. Nilai AVE berdasarkan tabel diatas, maka dapat disimpulkan bahwa konstruk dalam model yang diestimasi memenuhi kriteria discriminant validity.

c. Hasil Pengujian Composite Reliability dan Cronbach's Alpha

Tabel 5. Hasil Pengujian Composite Reliability

\begin{tabular}{lcc}
\hline \multicolumn{1}{c}{ Variabel } & Composite Reliability & Keterangan \\
\hline Gaya Kepemimpinan Situasional & 0.904 & Reliabel \\
Budaya Organisasi & 0.951 & Reliabel \\
Kompensasi & 0.887 & Reliabel \\
Kinerja Karyawan & 0.918 & Reliabel \\
\hline
\end{tabular}

Sumber: Output PLS

Tabel 6. Hasil Pengujian Cronbach's Alpha

\begin{tabular}{lcc}
\hline \multicolumn{1}{c}{ Variabel } & Cronbach'sAlpha & Keterangan \\
\hline Gaya Kepemimpinan Situasional & 0.889 & Reliabel \\
Budaya Organisasi & 0.935 & Reliabel \\
Kompensasi & 0.853 & Reliabel \\
Kinerja Karyawan & 0.892 & Reliabel \\
\hline
\end{tabular}

Sumber: Output PLS

Berdasarka Tabel 5 dan 6 bahwa hasil pengujian composite reliability dan cronbach's alpha menunjukan nilai yang memuaskan, karena seluruh variabel laten memiliki nilai composite reliability dan cronbach's alpha $\geq 0,70$. Hal ini berarti seluruh variabel laten dikatakan reliabel.

\section{Pengujian Model Struktural atau Uji Hipotesis (Inner Model)}

a. Hasil Pengujian Nilai R-square. Melihat nilai R-square yang merupakan uji goodnessfit model. 


\begin{tabular}{lcc}
\multicolumn{3}{c}{ Tabel 7. Nilai $\mathbf{R}^{\mathbf{2}}$ Variabel Endogen } \\
\hline Variabel Endogen & R-square & $\begin{array}{l}\text { R-square } \\
\text { Adjusted }\end{array}$ \\
\hline Kinerja Karyawan & 0.952 & 0.952 \\
\hline
\end{tabular}

Sumber: Output PLS

Model struktural mengindikasi bahwa model pada variabel kinerja karyawan dapat dikatakan kuat sebab memiliki nilai diatas 0.67. Model pengaruh variabel laten independen (Gaya kepemimpinan situasional, budaya organisasi, dan kompensasi) terhadap kinerja karyawan memberikan nilai R-square sebesar 0.952 yang dapat diinterprestasikan bahwa variabilitas konstruk kinerja karyawan yang dapat dijelaskan oleh variabilitas konstruk gaya kepemimpinan situasional, budaya organisasi, dan kompensasi sebesar $95.2 \%$ sedangkan $4.8 \%$ dijelaskan oleh variabel lain diluar yang diteliti.

b. Hasil Pengujian Goodness of Fit Model. Nilai R-square tiap-tiap variabel endogen dalam penelitian ini dapat dilihat pada perhitungan berikut ini:

Nilai predictive relevance diperoleh dengan rumus:

$$
\begin{aligned}
& Q^{2}=1-(1-R 1)\left(1-R_{p}\right) \\
& Q^{2}=1-(1-0.952) \\
& Q^{2}=1-0.048 \\
& Q^{2}=0.952
\end{aligned}
$$

Hasil perhitungan diatas memperlihatkan nilai predictive-relevance sebesar 0.952 yaitu lebih besar 0 (nol). Hal itu berarti bahwa $95.2 \%$ variasi pada variabel kinerja karyawan (variabel dependen) dijelaskan oleh variabel independen yang digunakan. Dengan demikian model dikatakan layak memiliki nilai prediktif yang relevan.

Hasil Pengujian Hipotesis (Estimasi Koefisien Jalur). Nilai estimasi untuk hubungan jalur dalam model structural harus signifikan. Nilai signifikansi pada hipotesis ini dapat diperoleh dengan prosedur boostrapping.Melihat signifikansi pada hipotesis dengan melihat nilai koefisien parameter dan nilai signifikansi T-statistik pada algorithm boostrapping report. Untuk mengetahui signifikan atau tidak signifikan dilihat dari $\mathrm{T}$ table pada alpha $0,05(5 \%)=1,96$, kemudian T-table dibandingkan dengan T-hitung (Tstatistik).

Tabel 8. Hasil Pengujian Hipotesis

\begin{tabular}{lccccl}
\hline & $\begin{array}{c}\text { Original } \\
\text { Sample }\end{array}$ & $\begin{array}{c}\text { Standard } \\
\text { Deviation }\end{array}$ & T-Statistics & $\begin{array}{c}\mathrm{P} \\
\text { Values }\end{array}$ & Keterangan \\
\hline $\begin{array}{l}\text { Gaya kepemimpinan } \\
\text { situasional } \rightarrow \text { Kinerja } \\
\text { karyawan }\end{array}$ & 0.095 & 0.034 & 2.779 & 0.006 & $\begin{array}{l}\text { Positif - } \\
\text { signifikan }\end{array}$ \\
$\begin{array}{l}\text { Budaya organisasi } \rightarrow \\
\text { Kinerja karyawan }\end{array}$ & 0.597 & 0.033 & 18.079 & 0.000 & $\begin{array}{l}\text { Positif - } \\
\text { signifikan }\end{array}$ \\
$\begin{array}{l}\text { Kompensasi } \rightarrow \\
\text { Kinerja karyawan }\end{array}$ & 0.380 & 0.033 & 11.497 & 0.000 & $\begin{array}{l}\text { Positif - } \\
\text { signifikan }\end{array}$ \\
\hline Sumber: Output PLS & & & & &
\end{tabular}


Pengaruh Gaya Kepemimpinan Situasional terhadap Kinerja Karyawan. Hasil ini menunjukan bahwa gaya kepemimpinan situasional berpengaruh positif dan signifikan terhadap kinerja karyawan. Hal ini terjadi karena produktivitas dan kemampuan berkinerja karyawan dalam perusahaan ini berbeda-beda, apabila kepemimpinan situasional ini diterapkan, maka para karyawan yang kurang dalam kinerjanya atau kemampuan dalam bekerja akan ditangani secara khusus, sehingga mengurangi kesalahan komunikasi terhadap karyawan yang kinerjanya membutuhkan bimbingan khusus. Hal ini terlihat dari pimpinan yang mampu memberikan perintah dan arahan yang jelas pada karyawannya dalam bekerja. Penelitian ini mendukung penelitian yang dilakukan oleh oleh Karma et al (2016), Wahyuni (2015), serta Hidayati et al (2015) yang menemukan bahwa gaya kepemimpinan situasional memiliki berpengaruh positif dan signifikan terhadap kinerja karyawan.

Pengaruh Budaya Organisasi terhadap Kinerja Karyawan. Hasil ini menunjukan bahwa budaya organisasi berpengaruh positif dan signifikan terhadap kinerja karyawan. Hal ini terjadi karena perusahaan mampu menciptakan budaya organisasi yang dapat membentuk karyawan menjadi taat terhadap aturan dan mengabdi kepada perusahaan. Terlihat dari disiplin para karyawan, perhatian karyawan terhadap perusahaan, dan fokus pada pekerjaan mereka yang berakibat meningkatnya kinerja karyawan. Selain itu, para karyawan menjadi saling menjalin hubungan yang baik antar rekan sekerja dalam menjalankan pekerjaan demi mewujudkan tujuan perusahaan. Penelitian ini sependapat dengan penelitian yang dilakukan oleh Fathoni et al., (2016), Wanjiku dan Agusioma (2014), serta Susetyo et al., (2014) yang menemukan bahwa budaya organisasi memiliki berpengaruh positif dan signifikan terhadap kinerja karyawan.

Pengaruh Kompensasi terhadap Kinerja Karyawan. Hasil ini menunjukan bahwa kompensasi berpengaruh positif dan signifikan terhadap kinerja karyawan.Hal ini terjadi dikarenakan karyawan merasakan kompensasi yang diberikan perusahaan baik kompensasi finansial maupun non finansial telah sesuai dengan kinerja mereka. Terlihat dari gaji, tunjangan dan insentif yang diberikan perusahaan kepada karyawan sesuai dengan kinerja yang diberikan karyawan terhadapperusahaan. Penelitian ini diperkuat oleh penelitian yang dilakukan oleh Nurcahyani dan Adnyani (2016), Njoroge dan Kwasira (2015), Fauzi (2014), Ramzan dan Ali (2014) yang menemukan bahwa kompensasi memiliki berpengaruh positif dan signifikan terhadap kinerja karyawan.

\section{PENUTUP}

Simpulan. Penelitian ini mencoba menganalisis variabel-variabel yang berkaitan dengan gaya kepemimpinan situasional, budaya organisasi, kompensasi, dan kinerja karyawan. Hasil penelitian ini diperoleh dari penelitian pada karyawan PT CIMB Niaga Cabang Kuningan Plaza. Dari hasil perhitungan dalam penelitian ini, maka dapat ditarik kesimpulan sebagai berikut: Pertama. Gayakepemimpinan situasional memberikan pengaruh positif dan signifikan terhadap kinerja karyawan PT CIMB Niaga Cabang Kuningan Plaza. Apabila gaya kepemimpinan situasional diterapkan dengan baik maka akan meningkatkan kinerja karyawan. Kedua. Budaya organisasi memberikan pengaruh positif dan signifikan terhadap kinerja karyawan PT CIMB Niaga Cabang Kuningan Plaza. Apabila budaya organisasi yang diterapkan perusahaan baik maka akan meningkatkan kinerja karyawan. Ketiga. Kompensasi memberikan pengaruh positif dan signifikan 
terhadap kinerja karyawan PT CIMB Niaga Cabang Kuningan Plaza. Apabila kompensasi yang diberikan tinggi dan sesuai dengan kinerja karyawan maka akan meningkatkan kinerja karyawan.

Saran. Berdasarkan kesimpulan di atas, maka dapat dikemukakan beberapa saran yang menjadi bahan pertimbangan bagi perusahaan PT CIMB Niaga Cabang Kuningan Plazamaupun bagi peneliti selanjutnya:

1) Saran untuk PT CIMB Niaga Cabang Kuningan Plaza. Bagi PT CIMB Niaga Cabang Kuningan Plaza, dari hasil penelitian variabel gaya kepemimpinan situasional terdapat indikator dengan nilai terendah pada pernyataan pimpinan selalu memberikan perintah kerja dengan jelas. agar karyawan mampu menerima arahan dan tugas yang diberikan oleh pimpinan dengan baik, pimpinan harus dapat menjelaskan setiap tugas masingmasing karyawan dengan jelas, dan karyawan harus belajar memahami dengan baik arahan dan tugas yang diberikan oleh pimpinan agar pekerjaan dapat terselesaikan secara optimal.

Dari hasil penelitian variabelbudaya organisasi terdapat indikator dengan nilai terendah pada pernyataan organisasi selalu mendorong karyawan untuk mampu menerima tugas dan tanggung jawab sesuai apa yang diberikan oleh atasan. Perusahaan juga harus terus memperbaiki budaya perusahaan agar karyawan dapat merasa terdukung dalam menerima tugas dan tanggung jawab yang diberikan atasan.

Dari hasil penelitian variabelkompensasi terdapat indikator dengan nilai terendah pada pernyataan perusahaan memberikan fasilitas kantor disetiap divisi.Perusahaan harus memberikan kompensasi sesuai dengan kinerja yang diberikan karyawan kepada perusahaan. Karyawan dalam bekerja sebaiknya memanfaatkan waktu dengan baik, agar dapat meningkatkan kinerja dan tercapainya tujuan perusahaan secara optimal.

2) Saran untuk Peneliti Selanjutnya

Saran untuk peneliti selanjutnya, peneliti selanjutnya harus bisa mengembangkan kembali variabel dan indikator yang belum digunakan dalam penelitian ini, peneliti selanjutnya dapat menggunakan variabel kepuasan kerja, kecerdasan emosional, gaya kepemimpinan, komitmen organisasi, dan lain sebagainya. Sebaiknya peneliti selanjutnya yang akan melakukan penelitian dalam bidang yang sama dan menggunakan skripsi ini sebagai referensi, maka kiranya perlu dikaji kembali karena tidak menutup kemungkinan ada pernyataan-pernyataan yang belum sesuai, karena saya sebagai penulis merasa masih banyak kekurangan dan keterbatasan dalam menyelesaikan skripsi ini.

\section{DAFTAR RUJUKAN}

Basrowi, Suwandi. (2010). Memahami Penelitian Kualitatif. Jakarta: Rineke Cipta.

Daft,L.Richard. (2012). Era Baru Manajemen, Salemba Empat - Jakarta.

Dessler, Gary.(2015). Manajemen Sumber Daya Manusia. Jakarta: Salemba Empat.

Djakasaputra, Arifin, Widayati, Christina Catur dan Septy (2017). "Pengaruh Gaya

Kepemimpinan Delegatif, Motivasi Kerja Dan Disiplin Kerja Terhadap Kinerja Karyawan Pada PT Bank Mandiri Kcp Jakarta Kota”, Jurnal Ekonomi, XXII (1), 8397 
Fathoni, Azis, dkk.(2016). "Pengaruh Budaya Organisasi, Kepemimpinan dan Motivasi Terhadap Komitmen Organisasi dan Kinerja Pegawai". Jurnal Manajemen, 2(2), 313.

Fauzi, Usman. (2014). "Pengaruh Kompensasi Terhadap Kinerja Karyawan pada PT Trakindo Utama Samarinda". Jurnal Ilmu Administrasi Bisnis, 2(3), 172-185.

Ghozali, Imam. (2014). Structural Equation Modelling: Metode Alternatif Dengan Partial Least Square (PLS). Badan penerbit, Universitas Diponegoro Semarang.

Handoko, T. H. (2010). Manajemen Personalia dan Sumber Daya Manusia. Edisi ke dua. Jogyakarta: BPFE.

Harvey, DF dan D.R. Brown. (2009). An Experiental Approach to Organization Development, Prentice Hall International, New Jersey.

Hasibuan, Malayu S.P. (2011). Manajemen Sumber Daya Manusia. Jakarta: PT Bumi Aksara.

Hasibuan, Malayu S.P. (2012). Manajemen Sumber Daya Manusia, edisirevisi. Jakarta: Bumi Aksara.

Hidayati, Siti, dkk. (2015). "Pengaruh Gaya Kepemimpinan Situasional Terhadap Kepuasan Kerja dan Kinerja Karyawan Studi Kasus Pada AirNav Indonesia Kantor Cabang Aero Traffic Control Soekarno Hatta”. Jurnal Administrasi Bisnis, 26 (1), 19.

Karma, Kadek Fajar Andika et al.(2016). "Pengaruh Gaya Kepemimpinan Situasional, Budaya Organisasi dan Motivasi pada Kinerja Karyawan di PT Bank Pembangunan Daerah Bali Cabang Badung”. Jurnal Ekonomi dan Bisnis,5 (11), 3823-3856.

Kartono, Kartini. (2010). Pemimpin dan Kepemimpinan. Jakarta: PT. Raja Grafindo Persada.

Khuong, Mai Ngoc dan Hoang D.T. (2015). "The Effects of Leadership Styles on Employee Motivation in Auditing Companies in Ho Chi Minh City, Vietnam”. Journal of Economics and Finance, 6(4), 210-217.

Mangkunegara, A.A Anwar Prabu. (2010). Evaluasi Kinerja Karyawan SDM, Cetakan Kelima. Jakarta: Refika Aditama.

Mangkunegara, A.A Anwar Prabu. (2011). Manajemen Sumber Daya Manusia Perusahaan. Cetakan ke 12. Bandung: PT Ramaja Rosdakarya.

Mangkunegara, A.A Anwar Prabu. (2013). Manajemen Sumber Daya Manusia Perusahaan, Remaja Rosdakarya, Bandung.

Marwansyah. (2010). Manajemen Sumber Daya Manusia, Edisi Kedua. Bandung: Alfabeta.

Mathis, Robert L. dan John, H. Jackson. (2009). Human Resource Management. Edisi 10. Jakarta : Salemba Empat.

Naor, M., Goldstein, S., M., Linderman, K., W. and Schroeder, R., G., (2008) The role of culture as driver ofquality management and performance: infrastructure versus core quality practices. Decision Sciences, 39 (4), 671-702.

Njoroge, Sheila Wambui dan Kwasira Josephat. (2015). "Influence of Compensation and Reward on Performance of Employees at Nakuru County Government". Journal of Business and Management,17(11), 87-93.

Nurcahyani, Ni Made, dkk. (2016). "Pengaruh Kompensasi dan Motivasi Terhadap Kinerja Karyawan dengan Kepuasan Kerja sebagai Variabel Intervening”. Jurnal Manajemen, 5(1), 500-532. 
Rahmat, Abdul and Widayati, Christina Catur., (2016). "Perceptual Mapping Leadership in Ethnic Regional Perspective (Studies in Six Ethnic Dominant Gorontalo)", International Journal of Economic Perspectives, 10 (2), 171-179.

Ramzan, Muhammad, dkk. (2014). "Impact of Compensation on Employee Performance (Empirical Evidence from Banking Sector of Pakistan)". Journal of Business, 5(2), 302-309.

Rivai, Veithzal. (2010). Manajemen Sumber Daya Manusia untuk Perusahaan : Dari Teori ke Praktik. Jakarta: Raja Grafindo Persada.

Rivai, Veithzal. dan Mulyadi, Deddy. (2012). Kepemimpinan dan Perilaku Organisasi. Edisi Ketiga. Jakarta: PT. Raja Grafindo Persada.

Robbins, S.P , dan Judge, T.A (2007). Organizational Behaviour. 12th edition. New Jersey: Pearson Education.

Robbins, Stephen \& Judge, T. (2011). Perilaku Organisasi Edisi 12 B. Jakarta: Salemba Empat.

Sadili, Samsudin. (2006). Manajemen Sumber Daya Manusia. Bandung: Penerbit Pustaka Setia.

Schein, E.H. (2009). Organizational culture and leadership. San Francisco: Jossey-Bass.

Sedarmayanti. (2011). Membangun dan Mengembangkan Kepemimpinan serta Meningkatkan Kinerja untuk Meraih Keberhasilan. Bandung: PT. Reflika Aditama.

Sinambela, Lijan Poltak, dkk. (2012). Kinerja Pegawai Teori Pengukuran dan Implikasi. Yogyakarta: Graha Ilmu.

Soedjono. (2005). "Pengaruh Budaya Organisasi terhadap Kinerja Organisasi dan Kepuasan Kerja Karyawan pada Terminal Penumpang Umum di Surabaya”. Jurnal Manajemen dan Kewirausahaan. 7(1), 23.

Susetyo, E. Widyanto, dkk. (2015). "Pengaruh Budaya Organisasi dan Lingkungan Kerja Terhadap kepuasaan kerja dan Kinerja Karyawan pada PT Bank Muamalat Indonesia Divisi Konsumer Area Cabang Surabaya". Jurnal Ilmu Ekonomi \& Manajemen, 1(1), 83-93.

Sutrisno, Edy. (2009). Manajemen Sumber Daya Manusia. Jakarta : Kencana Prenada Media.

Thoha, Miftah. (2010). Kepemimpinan dalam Manajemen, Jakarta: PT Raja Grafindo Persada.

Torang, Syamsir. (2013). Organisasi dan Manajemen: Perilaku, Struktur, Budaya dan Perubahan Organisasi. Bandung: Alfabeta.

Umar, Husein. (2010). Riset Pemasaran dan Perilaku Konsumen.Jakarta: Gramedia Pustaka Utama.

Wahyuni, Evi. (2015). "Pengaruh Budaya Organisasi dan Gaya Kepemimpinan Terhadap Kinerja Pegawai Bagian Keuangan Organisasi Sektor Publik dengan Motivasi Kerja sebagai Variabel Intervening”. Jurnal Manajemen, 4(1), 96-112.

Wanjiku, Njugi Anne dan Agusioma N.K. (2014). "Effect of Organisation Culture on Employee Performance in Non Govermental Organizations". Journal of Scientific and Research Publications, 4(11), 2250-2253.

Wibowo. (2010). Manajemen Kinerja, Edisi Ketiga. Jakarta: Rajawali Press.

Wirawan. (2009). Evaluasi Kinerja Sumber Daya Manusia Teori Aplikasi dan Penelitian. Jakarta. Penerbit: Salemba Empat. 